\title{
UV-ANALYTICAL METHOD DEVELOPMENT AND VALIDATION FOR SIMULTANEOUS ESTIMATION OF DAPOXETINE HYDROCHLORIDE AND SILDENAFIL CITRATE IN TABLET DOSAGE FORM
}

\author{
HEMESH GADIYA, MONIKA MAHESHWARI*, ASHOK DASHORA \\ Department of Quality Assurance, Geetanjali Institute of Pharmacy, Manwakhera NH-8 bypass, Udaipur, Rajasthan, India. \\ Email-mona30mph@gmail.com
}

Received: 25 September 2018, Revised and Accepted: 13 November 2018

\begin{abstract}
Objective: The objective of this research was to develop and validate a simple ultraviolet (UV) spectrophotometric method for simultaneous determination of sildenafil citrate and dapoxetine hydrochloride in a pharmaceutical formulation.

Methods: Two simple UV spectrophotometric methods have been developed for simultaneous determination of sildenafil citrate and dapoxetine hydrochloride. For both methods, stock solutions were prepared in methanol followed by the further required dilutions with methanol. Proposed dual-wavelength method and ratio derivative method, the wavelength of maximum absorption for sildenafil citrate and dapoxetine hydrochloride was $292 \mathrm{~nm}$ and $231 \mathrm{~nm}$, respectively.
\end{abstract}

Results: In both methods, the linearity range lies between 10 and $60 \mu \mathrm{g} / \mathrm{ml}$ for sildenafil citrate and 2-12 $\mu \mathrm{g} / \mathrm{mL}$ for dapoxetine hydrochloride with their respective wavelengths. By dual-wavelength method, the percentage of sildenafil citrate and dapoxetine hydrochloride was found to be $101.3 \%$ and $100.3 \%$, respectively.

Conclusion: Result obtained in this research work clearly indicated that both these methods were found to be accurate, precise, stable, and robust as indicated by low values of percentage relative standard deviation. Thus, the present study gives an excellent method for the determination of both the drugs in combined tablet formulation.

Keyword: Sildenafil citrate, Dapoxetine hydrochloride, Simultaneous estimation, Ultraviolet spectrophotometric methods.

(C) 2019 The Authors. Published by Innovare Academic Sciences Pvt Ltd. This is an open access article under the CC BY license (http://creativecommons. org/licenses/by/4. 0/) DOI: http://dx.doi.org/10.22159/ajpcr.2019.v12i1.29937

\section{INTRODUCTION}

Sildenafil citrate (SIL) and dapoxetine hydrochloride (DAPO) are available in a combined pharmaceutical dosage form for the treatment of erectile dysfunction, have a considerable impact on the research and medical communities. In 1996 sildenafil citrate was patented and in May 1998, it is launched as a first oral drug approved by the Food and Drug Administration in the United States. It is also used for the treatment of pulmonary arterial hypertension. Sildenafil citrate is white crystalline water-soluble powder with a molecular weight of 666.7 Dalton. The molecular formula is $\mathrm{C}_{22} \mathrm{H}_{30} \mathrm{~N}_{6} \mathrm{O}_{4} \mathrm{~S}$. Chemically, designated as 1-[[3-(6,7-dihydro-1-methyl-7-oxo-3-propyl-1H-pyrazolo[4,3-d] pyrimidin-5-yl)-4-ethoxyphenyl]sulfonyl]-4-methyl piperazine citrate. Its structural formula is given in Fig. $1[1,2]$.

When man arouses sexually, the parasympathetic nerves are stimulated leading to penile erection as result of release nitric oxide (NO) which works by activation of the enzyme guanylate cyclase responsible for converting guanosine triphosphate to $3^{\prime} 5^{\prime}$ cyclic guanosine monophosphate (cGMP). Sildenafil citrate selectively inhibits the enzyme phosphodiesterase-5A that hydrolyzes cGMP which is a potent vasodilator vital erection of the penis and increased the inflow of blood into the spongy tissue of the penis causing an erection by fascinating the signaling actions of NO in penile smooth muscle. The most common side effects of sildenafil citrate are facial flushing, headache, and upset stomach. Less commonly blurred vision, cyanopsia (bluish vision), or sensitivity to light may be briefly occur. Dapoxetine hydrochloride is mainly useful in erectile dysfunction as a selective serotonin reuptake inhibitor (SSRI). This drug is designated chemically as (S)-N, N-dimethyl3-(naphthalene-1-yloxy)-1 phenylpropane-1-amine with an empirical formula of $\mathrm{C}_{21} \mathrm{H}_{23} \mathrm{NO}$ and molecular weight of $305.413 \mathrm{~g}$. SSRI is a class of compounds typically used as antidepressants in the treatment of depression, anxiety disorders, and some personality disorders. They can also sometimes be effective and used in treating impotence, premature ejaculation problems, and in some cases of insomnia. This drug inhibits neuronal reuptake of serotonin and subsequent potentiating of serotonin activity and increases the ejaculation time. Its structural formula is given in Fig. 2 [1,2]. There is a need for development and validation of ultraviolet (UV) analytical method for simultaneous estimation of dapoxetine hydrochloride and sildenafil citrate for combined pharmaceutical dosage form. Here, two simple UV spectrophotometric methods were developed and validated for their simultaneous analysis.

\section{Experimental}

Instrumentation and apparatus

Double beam UV-visible spectrophotometer (Shimadzu Corporation, model UV 1800) was used having two matched quartz cells with $1 \mathrm{~cm}$ light path length. [3]

\section{Reagents}

Pure samples of sildenafil citrate and dapoxetine hydrochloride and their combination pharmaceutical preparations were collected from Astra Lifecare Pvt. Ltd., Ahmedabad. Methanol was used as solvents throughout the experiment.

Preparation of stock solution of dapoxetine hydrochloride Accurately weighed $10 \mathrm{mg}$ of dapoxetine hydrochloride was transferred into a $100 \mathrm{ml}$ volumetric flask and dissolved in small volume of 


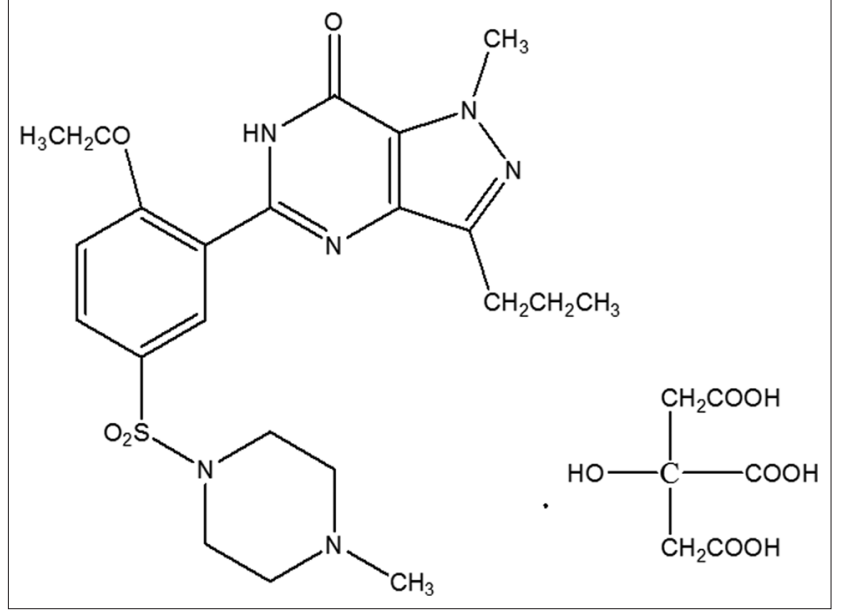

Fig. 1: Sildenafil Citrate

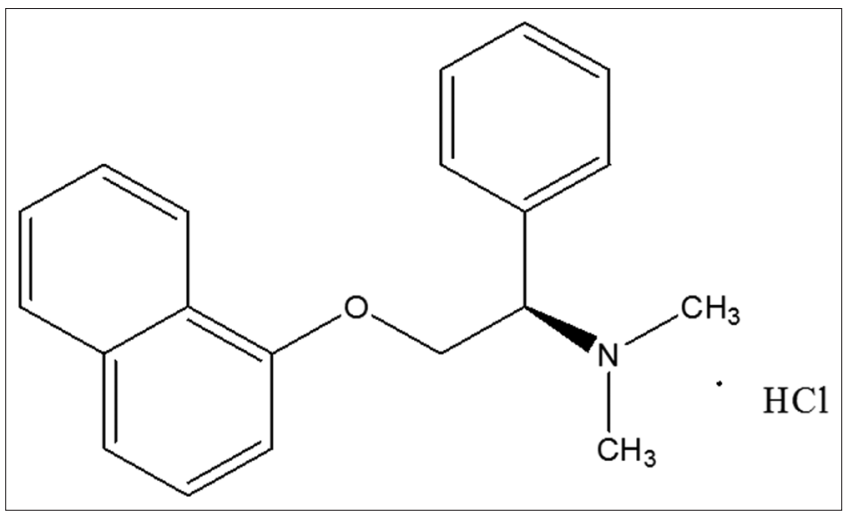

Fig. 2: Dapoxetine Hydrochloride

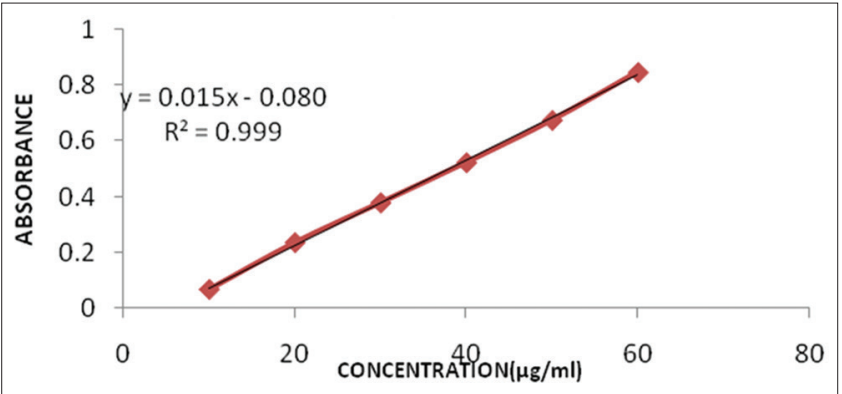

Fig. 3: Calibration curve data for sildenafil citrate standard

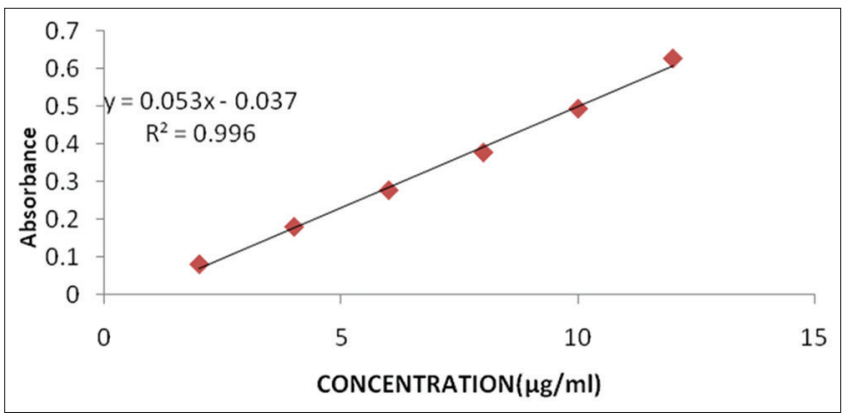

Fig. 4: Calibration curve data for dapoxetine hydrochloride standard

methanol. The volume was adjusted to the mark with methanol to obtain a final concentration of dapoxetine hydrochloride $(100 \mu \mathrm{g} / \mathrm{ml})$. $1 \mathrm{ml}$ of this solution was transferred in a $10 \mathrm{ml}$ volumetric flask, and

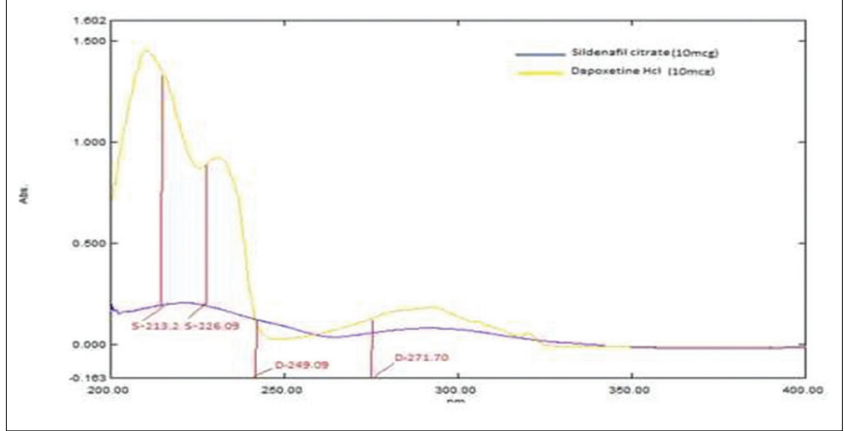

Fig. 5: Overlay spectra of sildenafil citrate and dapoxetine hydrochloride

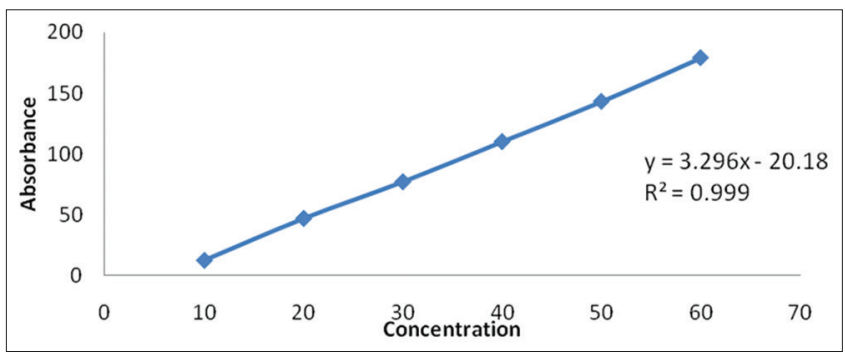

Fig. 6: Calibration curve of sildenafil citrate

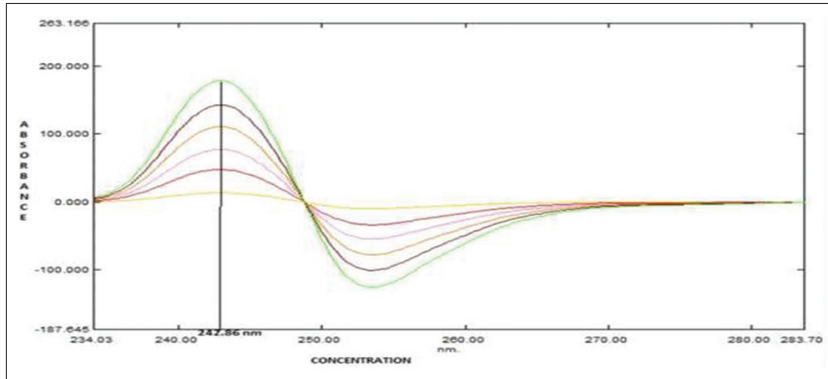

Fig. 7: Ratio first derivative absorption spectra of DAPO $(2-12 \mu \mathrm{g} / \mathrm{ml}$

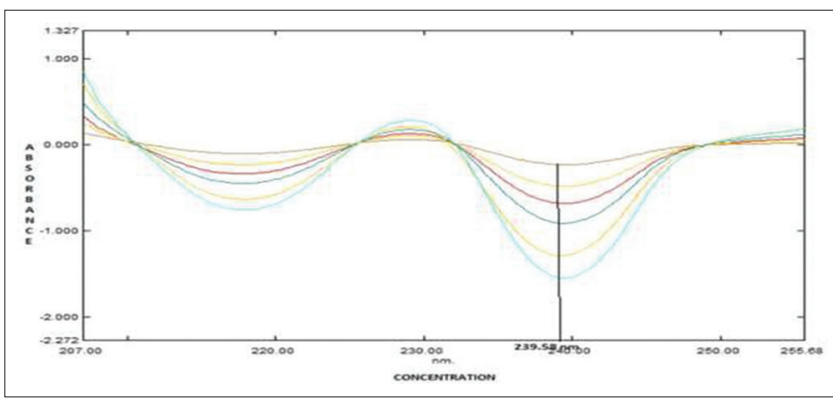

Fig. 8: Ratio first derivative absorption spectra of sildenafil citrate $(10-60 \mu \mathrm{g} / \mathrm{ml0029}$

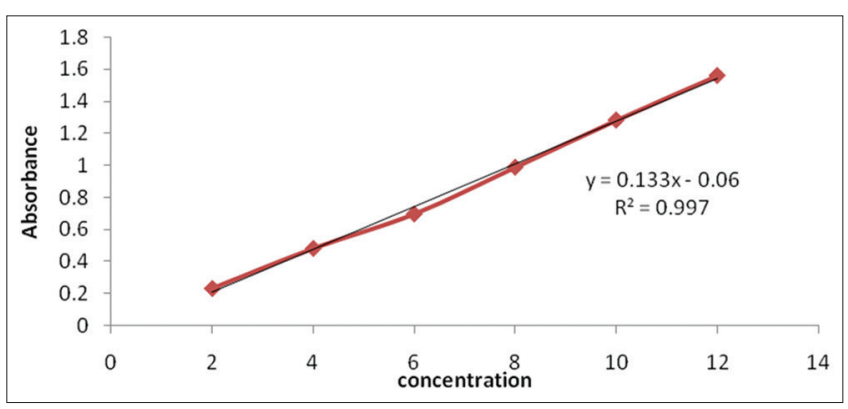

Fig. 9: Calibration curve of dapoxetine hydrochloride 
Table 1: Linear regression parameters for dapoxetine hydrochloride and sildenafil citrate by duel wave lenght method

\begin{tabular}{lll}
\hline Parameters & $\begin{array}{l}\text { Sildenafil } \\
\text { citrate }\end{array}$ & $\begin{array}{l}\text { Dapoxetine } \\
\text { hydrochloride }\end{array}$ \\
\hline Linearity range $(\mu \mathrm{g} / \mathrm{ml})$ & $10-60$ & $2-12$ \\
Correlation coefficient $\left(\mathrm{r}^{2}\right)$ & 0.9991 & 0.9954 \\
Slope $\pm \mathrm{SDb}(\mathrm{Sb})$ & $0.0153 \pm 0.00015$ & $0.0053 \pm 0.00023$ \\
Confidence limit of slope & $0.00143-0.0160$ & $0.00507-0.0056$ \\
Intercept $\pm \mathrm{SDb}(\mathrm{Sa})$ & $0.0808 \pm 0.00245$ & $0.0329 \pm 0.00146$ \\
Confidence limit of intercept & $0.0557-0.1060$ & $0.0483-0.0584$ \\
LOD $(\mu \mathrm{g} / \mathrm{ml})$ & 0.5282 & 0.0904 \\
LOQ $(\mu \mathrm{g} / \mathrm{ml})$ & 1.6006 & 0.2741 \\
Bartlett's test ${ }^{\mathrm{a}}\left(\chi^{2}\right)$ & 0.8698 & 1.0673 \\
\hline
\end{tabular}

${ }^{\mathrm{b}}$ Mean of five determinations, a should be $<5.991$ at $95 \%$ confidence interval,

LOD: Limit of detection, LOQ: Limit of quantitation

Table 2: Linear regression parameters for dapoxetine hydrochloride and sildenafil citrate by ratio derivative method

\begin{tabular}{lll}
\hline Parameters & $\begin{array}{l}\text { Sildenafil } \\
\text { citrate }\end{array}$ & $\begin{array}{l}\text { Dapoxetine } \\
\text { hydrochloride }\end{array}$ \\
\hline Linearity range $(\mu \mathrm{g} / \mathrm{ml})$ & $10-60 \mu \mathrm{g} / \mathrm{ml}$ & $2-12 \mu \mathrm{g} / \mathrm{ml}$ \\
Correlation coefficient $\left(\mathrm{r}^{2}\right)$ & 0.9995 & 0.9965 \\
Slope $\pm \mathrm{SD}^{\mathrm{b}}\left(\mathrm{S}_{\mathrm{b}}\right)$ & $3.2965 \pm 0.0011$ & $0.1336 \pm 0.00023$ \\
Confidence limit of slope & $3.1919-3.4011$ & $0.1226-0.1444$ \\
Intercept $\pm \mathrm{SD}^{\mathrm{b}}\left(\mathrm{S}_{\mathrm{a}}\right)$ & $20.185 \pm 0.00403$ & $0.0627 \pm 0.00177$ \\
Confidence limit of intercept & $16.122-24.256$ & $0.02257-0.1479$ \\
LOD $(\mu \mathrm{g} / \mathrm{ml})$ & 0.00404 & 0.0439 \\
LOQ $\left(\mu \mathrm{g} / \mathrm{ml}^{\prime}\right)$ & 0.01224 & 0.1330 \\
Bartlett's test ${ }^{\mathrm{a}}\left(\chi^{2}\right)$ & 0.8247 & 0.8959 \\
\hline
\end{tabular}

${ }^{b}$ Mean of five determinations, a should be $<5.991$ at $95 \%$ confidence interval, $\mathrm{n}=5$. LOD: Limit of detection, LOQ: Limit of quantitation

volume was adjusted to the mark with methanol, to prepare a final concentration of $10 \mu \mathrm{g} / \mathrm{ml}$ [4].

\section{Preparation of stock solution of sildenafil citrate}

Accurately weighed $10 \mathrm{mg}$ of sildenafil citrate was transferred into a $100 \mathrm{ml}$ volumetric flask and dissolved in small volume of methanol. The volume was adjusted to the mark with methanol to obtain a final concentration of sildenafil citrate $(100 \mu \mathrm{g} / \mathrm{ml}) .1 \mathrm{ml}$ of this solution as transferred in a $10 \mathrm{ml}$ volumetric flask and volume was adjusted to the mark with methanol, to prepare a final concentration of $10 \mu \mathrm{g} / \mathrm{ml}$.

\section{Dual-wavelength method}

\section{Selection of wavelength for dual wavelength}

Dual-wavelength method was used for estimation of sildenafil citrate and dapoxetine hydrochloride; in this method, two wavelengths are required for one drug where one drug shows similar absorbance, but other drug shows the difference in absorbance. Two wavelengths were selected at which sildenafil citrate showed similar absorbance while other drug dapoxetine hydrochloride showed a considerable difference in absorbance. The other two wavelengths were selected such that dapoxetine hydrochloride showed similar absorbance while sildenafil citrate showed a considerable difference in absorbance (Fig.5).

\section{Analysis of formulation}

Twenty tablets (label claim of $100 \mathrm{mg}$ sildenafil citrate and $60 \mathrm{mg}$ dapoxetine hydrochloride) were weighed and finely powdered. Powder equivalent to $100 \mathrm{mg}$ sildenafil citrate and $60 \mathrm{mg}$ dapoxetine hydrochloride was accurately weighed and transferred to $100 \mathrm{ml}$ volumetric flask addition of methanol and sonicated for $15 \mathrm{~min}$. The volume was made up to mark with methanol. The solution was filtered through Whatman filter paper $(0.45 \mu)$. From this solution, $1 \mathrm{ml}$ was transferred to the $10 \mathrm{ml}$ volumetric flask and volume made up to the mark to give a solution containing $10 \mu \mathrm{g} / \mathrm{ml}$ sildenafil citrate and $6 \mu \mathrm{g} / \mathrm{ml}$ dapoxetine hydrochloride. This solution was used for the estimation of sildenafil citrate and dapoxetine hydrochloride [5-7].

\section{Ratio derivative method \\ Selection of analytical wavelength}

Zero-order spectra of standard solution of sildenafil citrate and dapoxetine hydrochloride were recorded and further, spectra were divided by $8 \mu \mathrm{g} / \mathrm{ml}$ dapoxetine hydrochloride and $40 \mu \mathrm{g} / \mathrm{mL}$ sildenafil citrate, respectively, and these ratio spectra of sildenafil citrate and dapoxetine hydrochloride were converted into first derivative, and absorbance at wavelength $242.68 \mathrm{~nm}$ and $239.58 \mathrm{~nm}$ was determined for estimation sildenafil citrate and dapoxetine hydrochloride, respectively.

\section{Analysis of formulation}

Twenty tablets (label claim of $100 \mathrm{mg}$ sildenafil citrate and $60 \mathrm{mg}$ dapoxetine hydrochloride) were weighed and finely powdered. Powder equivalent to $100 \mathrm{mg}$ sildenafil citrate and $60 \mathrm{mg}$ dapoxetine hydrochloride was accurately weighed and transferred to the $100 \mathrm{ml}$ volumetric flask followed by addition of methanol and sonicated for $15 \mathrm{~min}$. The volume was made up to mark with methanol. The solution was filtered through Whatman filter paper $(0.45 \mu)$. From this solution, $1 \mathrm{ml}$ was transferred, to $10 \mathrm{ml}$ volumetric flask and diluted up to mark to give a solution containing $10 \mu \mathrm{g} / \mathrm{ml}$ sildenafil citrate and $6 \mu \mathrm{g} / \mathrm{ml}$ dapoxetine hydrochloride. This solution was used for the estimation of sildenafil citrate and dapoxetine hydrochloride.

\section{DETERMINATION OF SILDENAFIL CITRATE AND DAPOXETINE HYDROCHLORIDE BY RATIO FIRST DERIVATIVE SPECTROPHOTOMETRIC METHOD}

The standard stock solution was used for the preparation of the solution in the calibration range of $10-50 \mu \mathrm{g} / \mathrm{mL}$ of sildenafil citrate and $2-12 \mu \mathrm{g} /$ $\mathrm{mL}$ of dapoxetine hydrochloride in methanol in $10 \mathrm{ml}$ of volumetric flask. Selection of devisor concentration is done by the division of the mixture's spectrum by the spectrum of one fixed component named "divisor." Then, the derivative ratio spectrum of that mixture will be independent on that component "divisor," and the other component can be determined with no interference. Different concentrations of sildenafil citrate $(10,20,30$, $40,50$, and $60 \mu \mathrm{g} / \mathrm{ml})$ and of dapoxetine hydrochloride $(2,4,6,8,10$, and $12 \mu \mathrm{g} / \mathrm{ml}$ ) were tested as a divisor but the concentrations $40 \mu \mathrm{g}$ / $\mathrm{ml}$ of sildenafil citrate and $8 \mu \mathrm{g} / \mathrm{ml}$ of dapoxetine hydrochloride gave minimum noise in ratio spectra, best linearity, and maximum sensitivity. Final selected divisor concentration for sildenafil citrate $(8 \mu \mathrm{g} / \mathrm{ml})$ and dapoxetine hydrochloride $(40 \mu \mathrm{g} / \mathrm{ml})$ [9].

\section{RESULTS}

\section{Dual-wavelength method}

The overlay spectrum of sildenafil citrate and dapoxetine hydrochloride at different concentrations revealed that at $213.2 \mathrm{~nm}$ and $226.09 \mathrm{~nm}$ different concentrations of sildenafil citrate showed similar absorbance whereas dapoxetine hydrochloride showed a significant difference in the absorbance. In a similar manner, at $242.09 \mathrm{~nm}$ and $271.70 \mathrm{~nm}$, different concentrations of dapoxetine hydrochloride showed similar absorbance whereas sildenafil citrate showed a significant difference in absorbance. Considering above facts, wavelength $242.09 \mathrm{~nm}$ and $271.70 \mathrm{~nm}$ were selected for the estimation of sildenafil citrate while $213.2 \mathrm{~nm}$ and $226.09 \mathrm{~nm}$ were selected for the estimation of dapoxetine hydrochloride (Table 1).

\section{Linearity}

The linearity was assessed by ordinary linear regression analysis. The constructed calibration curve was linear over the concentration range of $2-12 \mu \mathrm{g} / \mathrm{ml}$ and $10-60 \mu \mathrm{g} / \mathrm{ml}$, the linear regression equation was $\mathrm{Y}=0.0534 \mathrm{x}-0.0329$ and $\mathrm{Y}=0.0153 \mathrm{x}-0.0808$ with regression coefficient of 0.9954 and 0.9991 for dapoxetine and sildenafil, respectively. The result shows that the calculated $\chi^{2}$ value is less than the critical value at $95 \%$ confidence interval, $\chi^{2}(0.05,5)=9.488$; thus, indicating that the variance of response is homogeneous (Figs. 3,4, 6 and 9). 
Limit of detection (LOD) and limit of quantitation (LOQ)

LOD and LOQ for dapoxetine hydrochloride were found to be $0.09047 \mu \mathrm{g} / \mathrm{ml}$ and $0.27416 \mu \mathrm{g} / \mathrm{ml}$ and for sildenafil citrate were found to be $0.5282 \mu \mathrm{g} / \mathrm{ml}$ and $1.6006 \mu \mathrm{g} / \mathrm{ml}$, respectively.

\section{Precision}

Results of intraday show percentage relative standard deviation (RSD) below 0.923 and 0.955 while interday results show percentage RSD below 0.650 and 1.777, respectively, for sildenafil and dapoxetine. The values were $<2 \%$ thus demonstrating good repeatability and reproducibility of the method.

\section{Accuracy}

The proposed method afforded recovery of $100.51-101.91 \%$ after spiking the standard drug at three concentration levels of 50,100, and $150 \%$. The values of percentage recovery and percentage RSD for both drugs percentage RSD were found to be $<2 \%$ which indicate that the proposed method was accurate [10].

\section{Ratio derivative method}

Ratio spectra of sildenafil citrate were obtained by dividing the zeroorder spectra of sildenafil citrate $(10-60 \mu \mathrm{g} / \mathrm{ml})$ by the spectrum of a standard solution of dapoxetine hydrochloride $(8 \mu \mathrm{g} / \mathrm{ml})$. The obtained ratio spectra of sildenafil citrate were converted into firstorder derivative (D1) spectra. Likewise, a ratio spectrum of dapoxetine hydrochloride was obtained by dividing zero-order spectra of dapoxetine hydrochloride $(2-12 \mu \mathrm{g} / \mathrm{ml})$ by the spectrum of standard solution of sildenafil citrate $(40 \mu \mathrm{g} / \mathrm{ml})$. The obtained spectra of dapoxetine hydrochloride were converted into the first-order derivative (D1) spectra with the interval of $\Delta \lambda=8 \mathrm{~nm}$ and scaling factor 20 . The concentrations of selected analyte were quantified by measuring the amplitude maxima of the respective analyte from their first-order derivative (D1) spectrum at $\lambda$ of $242.68 \mathrm{~nm}$ and $239.58 \mathrm{~nm}$ for sildenafil citrate and dapoxetine hydrochloride, respectively $[7,8]$ (Table 2 and Figs.7,8).

\section{Linearity}

The sildenafil citrate and dapoxetine hydrochloride showed good correlation coefficient $\mathrm{r}^{2}=0.9995$ and $\mathrm{r}^{2}=0.9968$, respectively, in the given concentration range of $10-60 \mu \mathrm{g} / \mathrm{ml}$ for sildenafil citrate and $2-12 \mu \mathrm{g} / \mathrm{ml}$ for dapoxetine hydrochloride. The result shows that the calculated $\chi^{2}$ value is less than the critical value at $95 \%$ confidence interval, $\chi^{2}(0.05$, 5 ) $=9.488$; thus indicating that the variance of response is homogeneous.

\section{LOD and LOQ}

LOD and LOQ for dapoxetine hydrochloride were found to be $0.0439 \mu \mathrm{g} / \mathrm{ml}$ and $0.1330 \mu \mathrm{g} / \mathrm{ml}$ and for sildenafil citrate were found to be $0.0040 \mu \mathrm{g} / \mathrm{ml}$ and $0.1224 \mu \mathrm{g} / \mathrm{ml}$, respectively, individually high sensitivity of the method.

\section{Precision}

Results of intraday precision show percentage RSD below 0.005 and 0.077 , while interday precision results show percentage RSD below 0.015 and 0.222 , respectively, for sildenafil citrate and dapoxetine hydrochloride. The values were $<2 \%$, thus demonstrating good repeatability and reproducibility of the method.

\section{Accuracy}

The proposed method afforded recovery of $100.40-101.26 \%$ after spiking the standard drug at three concentration levels of 50,100, and $150 \%$. The values of percentage recovery and percentage RSD for both drugs percentage RSD were found to be $<2 \%$ which indicate that the proposed method was accurate.

\section{DISCUSSION}

Sildenafil citrate and dapoxetine hydrochloride are available in the combined pharmaceutical dosage form. Earlier, the various UV analytical methods for sildenafil citrate $[5,11,12,13]$ and dapoxetine hydrochloride $[1,6,14]$ have been reported for bulk drug or in a combination of other drugs, but till now no analytical research work on the combination of sildenafil citrate and dapoxetine hydrochloride has been reported. Thus, this research work is useful for simultaneous estimation of dapoxetine hydrochloride and sildenafil citrate for combined pharmaceutical dosage form. The standard deviation and RSD of the methods are low, indicating a high degree of precision of the methods. The developed methods are simple, rapid, precise, and accurate and can be employed for the routine estimation of sildenafil citrate and dapoxetine hydrochloride.

\section{CONCLUSION}

The introduction of sildenafil citrate and dapoxetine hydrochloride has had a considerable impact on the research and medical communities. It has led to an increasing interest in sexual medicine, both in academia, in clinical practice and the pharmaceutical industry. Several large pharmaceutical companies are searching for new treatments for male erectile dysfunction and premature ejaculation. In the future, we can anticipate a wide array of treatments for male erectile disorder and premature ejaculation hopefully some breakthroughs in the treatment of other sexual disorders.

\section{ACKNOWLEDGMENTS}

Authors are also thankful to the management of Astra Lifecare Pvt. Ltd., and Geetanjali Institute of Pharmacy, Udaipur, for providing necessary facilities.

\section{AUTHORS' CONTRIBUTION}

All the authors have contributed equally.

\section{CONFLICTS OF INTEREST}

The authors declare that they have no conflicts of interest.

\section{REFERENCES}

1. Kumar KA, Velmurugan R. Development and validation of UV spectroscopy method for the determination of dapoxetine hydrochloride in pharmaceutical formulation. J Pharm Res 2012;5:1949-51.

2. Giri AD, Bhasari VK, Dhaneshwar SR. HPLC method for simultaneous quantitation of tadalafil and dapoxetine hydrochloride in bulk drug and formulation qutanation. J Pharm Pharm Sci 2012;14:654-8.

3. Fronk AS. Handbook of Instrumental Techniques for Analytical Chemistry. $1^{\text {st }}$ ed. London: Pearson Education; 2004. p. 121-49.

4. Swarbrick J, Boylan JC. Encyclopedia of Pharmaceutical Technology. New York: Marcel Dekker Inc.; 1998. p. 217-24.

5. Atipairin A, Woradechakul C, Chee SK, Sawatdee S, Yoon SA. Method validation for determination of sildenafil citrate in extemporaneous oral suspension. Int J Pharm Pharm Sci 2014;6:131-6.

6. Banik S. A simple and rapid validated UV spectrophotometric method for estimation of dapoxetine in bulk and tablet dosage form. Indian $\mathrm{J}$ Novel Drug Deliv 2014;6:277-82.

7. Suruse SD, Jadhav KB. Dual wavelength spectrophotometric method for simultaneous estimation of telmisartan and indapamide in their combined dosage form. Int J Pharm Life Sci 2013;1:85-92.

8. Abdelwahab NS, Zeiny BA. Two spectrophotometric methods for simultaneous determination of some antihyperlipidemic drugs. J Pharm Anal 2012;2:279-84

9. Palabiyik IM, Dinç E, Onur F. Simultaneous spectrophotometric determination of pseudoephedrine hydrochloride and ibuprofen in a pharmaceutical preparation using ratio spectra derivative spectrophotometry and multivariate calibration techniques. J Pharm Biomed Anal 2004:34:473-83

10. FDA Guidance for Industry. Analytical Procedures and Method Validation, Chemistry, Manufacturing, and Controls Documentation, Center for Drug Evaluation and Research (CDER) and Center for Biologics Evaluation and Research (CBER); 2000.

11. The United States Pharmacopeia. 35-National Formulary 30. Rockville, Md: The United States Pharmacopeial Convention; 2012. p. 260-5.

12. Sakur AA, Affas S. Validated spectrophotometric method to determine verdenafil and sildenafil in pharmaceutical forms using potassium iodide and potassium iodate. Int J Pharm Pharm Sci 2017:9:65-9.

13. Baddenapalli T, Gandz V. Indirect spectrophotometric estimation of drugs using cerium (IV) and rhodamine-b as analytical reagents. Int $\mathrm{J}$ Pharm Pharm Sci 2015;8:62-6.

14. Kanani VV, Muralikrishna KS. Development and validation of UV spectrophotometric method for estimation of dapoxetine $\mathrm{HCl}$ in bulk and dosage form. Int J Drug Dev Res 2013;5:161-7. 